\title{
Redlining in Residential Mortgages in Johannesburg, South Africa
}

\author{
Charles Muzi Nsibande \\ Bogoje Properties, Kyalami 1684, South Africa
}

\begin{abstract}
The aim of the research in the paper was to study redlining practice within the greater Johannesburg area. The aim can be summarised by the following objectives: firstly, to investigate the evidence of redlining in the Greater Johannesburg area and to test its existence; secondly, to investigate the reasons why the areas were redlined; thirdly, to understand what the South Africa government and society did to combat the redlining practice. The research methodology was based on a questionnaire and interviews. A pool of respondents from the Greater Johannesburg suburbs that had interest or were affected by the practice of redlining was sought and interviewed. Analysis of the responses was made and conclusions were drawn from the responses. Secondary data was also sought from publications on the redlining practice to support the primary interviews data. From the interview responses and the secondary data, it was established that redlining existed in Greater Johannesburg and that the areas where redlining was practised could be marked on a map.
\end{abstract}

Key words: Mortgages, mortgage risk, redlining, reinvestment.

\section{Introduction}

The term "redlining" was coined in the late 1960s by John McKnight, a Northwestern University sociologist and community activist. It describes the practice of marking a red line on a map to delineate the area where banks would not invest. Later, the term was applied to discrimination against a particular group of people (usually by race or sex) regardless of the geography.

Even though the practice is widely reported in the United States, redlining occurs in many developed economies of the world, especially in the major cities of developed countries. The exposure of the practice in the United States is a result of the legislation framework that has been developed to combat redlining.

McKnight in the 1960s defined redlining as the practice of denying or increasing the cost of services such as banking, insurance, access to jobs, access to

Corresponding author: Charles Muzi Nsibande, M.Sc., research fields: real estate and construction management. E-mail: m_nsibande@yahoo.co.uk. health care or even supermarkets to residents in certain areas. Redlining is associated with a geographical area rather than a population profile. In the earlier days of redlining, a line would be drawn on a map by a mortgage lender, showing an area where the lender would not grant mortgage bonds.

The main debate in the paper was between the mortgage lenders and the mortgage seekers. The debates were based on the reasons for redlining: why mortgage lenders practice redlining. The mortgage lenders' arguments were based on finance and default risk principles, whereas the mortgage seekers based their arguments on socio-economic issues and their rights to access to finance in order to improve their economic status.

This paper is based on research carried out in 1997 and 1998. The findings, reported in this paper, are based on interviews with the stakeholders: mortgage seekers and mortgage lenders, which consisted of four major banks in Johannesburg. The research was carried out in Johannesburg and included interviewing the heads of mortgage lenders from ABSA 
(Amalgamated Bank of South Africa) Bank, Standard Bank, Nedcor Bank (now Nedbank), Allied Bank (now part of ABSA Bank) and First National Bank. Interviews were also carried out with five estate agents that operated mainly in the inner-city of Johannesburg and other areas in Johannesburg that could make comparison of the difference (if any) in banks' treatment of different areas in Greater Johannesburg. There were also interviews with property companies, property management companies and property developers that have a portfolio of properties in Greater Johannesburg, including the inner-city. Interviews were also done with mortgage seekers which consisted of people who were living in the inner-city or intended to live in the inner-city in the near future.

The paper seeks to address three key issues:

(1) whether there was redlining in greater Johannesburg;

(2) the reasons why mortgage lenders redlined certain areas;

(3) what the South African government and society did to eradicate redlining.

\section{Literature Review}

\subsection{Existence of Redlining}

As far back as 1978, a study in Newcastle Upon Tyre, United Kingdom, by Kirby [1] indicated that some districts in the city were entirely overlooked by building society associations funds usually on the grounds of the age of the properties. In fact, it was commonly assumed that many building society associations operated a system of redlining, whereby certain inner-city districts are regarded as off limits to investment.

In South Africa, in the 1990s, a similar practice, whereby the South African Weekly Mail [2] was quoted, "a red menace is spreading through the leafy northern suburbs of Johannesburg: not communists in the shrubbery by bank redlining policies in the figurative line demarcates a no lend area”. A study carried out by the HSRC (Human Sciences Research Council) in 1991 found evidence of redlining in Johannesburg and supported the inner-city phenomenon. The study found that redlining in Greater Johannesburg was dominant in Hillbrow, Berea, Joubert Park and the CBD (central business district) residential, which are all within the inner-city boundaries of Johannesburg. Crankshaw and White [3] wrote in their paper, "Racial desegregation and the origin of slums in Johannesburg's inner-city” also found evidence of redlining in Johannesburg. Crankshaw and White noted racial bias and argued that allowing non-whites to live in the inner-city of Johannesburg contributed in the redlining of the "grey areas" by financial institutions before the new interracial and democratic government of 1994. Nsibande [4] found evidence, in his research, of the practice of redlining in the Greater Johannesburg area.

In the United States of America, Holmes [5] wrote in his article "Neighborhood racial composition and mortgage redlining: A nationwide analysis” found that redlining was also widely practiced in the USA across the whole country. Holmes's study provided statistical evidence that neighborhood racial composition may affect the flow of mortgage credit in some regions. Squires et al. [6] have published many findings of the practice of redlining in residential mortgages in the United States of America.

From the above articles, it is clear that redlining is widely practiced in many areas around the world. This makes it necessary to seek an understanding behind the reasons for redlining in mortgage lending: why financial institutions practice it.

\subsection{Reasons for Redlining}

\subsubsection{Risk Versus Return}

In modern finance theory, Sharpe [7] explains best how an investor prices assets in uncertainty. The capital asset pricing model, developed by Sharpe, explains that an investor requires higher returns from more risky assets as compensation for the additional 
risk taken on the more risky asset. The theory is widely applicable in pricing of investment instruments and can be applied to residential mortgages. In residential mortgages, applying this principle means that a mortgage lender will require a higher return from granting mortgages in higher risk areas. Hence, areas that mortgage lenders perceive as more risky will be expected to yield higher returns for the mortgage lender to compensate for the additional risk a mortgage lender is taking.

\subsubsection{Pricing of Residential Mortgage Loans}

In areas that mortgage lenders perceive as risky, the mortgages must be priced to an extent sufficient for the mortgage lender to compensate the risk being taken. In an ideal market, the mortgage lender could price the mortgages "high enough" to compensate whatever risk being taken in the lending to a risky area. However, legislation and market forces prevent the mortgage lenders from going "high enough" to cover all their risk. Therefore, mortgage lenders are limited to a cap on the interest or required return that they can charge on a mortgage loan. This means that if the mortgage lender has a limit or a cap, the mortgage lenders would not be sufficiently compensated which compels the mortgage lender to abstain from making that investment. This results in redlining of areas that are perceived to be too risky or areas where the mortgage lenders cannot charge sufficient interest to cover the additional risk they are taking.

A mortgage lender will only grant a mortgage loan if the interest charge compensates for the required return on the investment.

\subsection{Combating Redlining in the USA}

In the United States, it is easier to investigate and charge the mortgage lenders because of the "Home Mortgage Disclosure Act of 1975" and the “Community Re-Investment Act of 1977”. These two laws work hand in hand. The disclosure act requires financial institutions to release their mortgage lending records, including rejections. If there is evidence of redlining based on the data released under the disclosure act, the Community Re-Investment Act mandates the financial institutions (culprits) to provide access to home mortgage loans through their local branches and service the local areas. Nowadays, there are other laws that support these two acts like the Equal Credit Opportunity Act.

In recent times, there are several other organisations and state institutions who monitor financial institutions' mortgage lending practices. To name a few, there is the ACORN (Association of Community Organisations for Reform Now), Greenlining Coalition (San Francisco group) and the SCLC (Southern Christian Leadership Conference). In recent years, these organisations have advised minority group in the United States to deposit their savings with minority banks to avoid being discriminated in cases where certain financial institutions proved to be practicing discrimination. With the help of these organisations, communities have managed to bring forward charges of redlining in Baltimore, Chicago, Atlanta and Los Angeles. According to Roberts [8], in some instances, there has been compensation paid out to communities, as it was the case in Hartford. In this case, the Justice Department, Federal Reserve of Hartford, and the Federal Trade Commission ordered Shawnut National Corporation to pay one million dollars in a discrimination suit in mortgage lending before they could be granted permission to operate in Hartford. Shawnut National Corporation had to find seventy to one hundred people to share the one million dollars compensation.

\section{Research Methodology}

The research in this paper was based on interviews carried out in 1997 and 1998 in Greater Johannesburg. The participants in the research were made up of mortgage seekers, consisting of estate agents, home owners, valuers and property professionals, civic organisations and council employees, and mortgage lenders, consisting of the four major banks in 
Johannesburg, namely, Standard Bank, ABSA Bank, Allied Bank (now part of ABSA Bank), First National Bank and Nedbank.

The interview methodology consisted of a standard questionnaire with 10 questions. All the interviews that had the same format and did not discriminate if you were a mortgage seeker of mortgage lender. To avoid bias, all interviews had the same format and the same questions were asked with everyone that participated in the research. Questions sought to address the research questions: if there was any redlining, extent of redlining and areas where they had experienced redlining. Additional questions sought to understand if the participants understood the meaning of redlining and what the impact would be of the practice in the redlined areas.

\section{Findings and Discussion}

\subsection{Mortgage Seekers}

\subsubsection{Estate Agents}

The mortgage seekers all agreed to the existence of redlining in Greater Johannesburg. Two contradicting views were expressed by the mortgage seekers as to why mortgage lenders were practicing redlining. One group found redlining policies justifiable while the other found the redlining policies detrimental to the real estate industry.

The first group believed that redlining policies were economic and financial measures applied by the mortgage lenders to protect themselves against unwanted and unnecessary exposure to risk. The estate agents believed that redlined areas were not conducive for investment and accepted that such areas should be redlined. They emphasized the importance of client profiles of the applicants rather than the area and believed the redlined areas were a result of poor credit worthiness. The estate agents emphasized that a good applicant with low default risk could get a mortgage bond in any area irrespective of whether the applicant believed an area was redlined or not. This view was supported by arguments made by mortgage lenders to be discussed in later sections of this paper. It was a hard line approach to the subject and it was worth exploring and debating with the estate agents who supported that view.

The latter group believed the mortgage lenders' redlining policies were not justifiable and were in fact worsening the condition and environment of the areas already redlined. The estate agents believed the mortgage lenders were critical players in unlocking the potential of areas and were controlling the destiny of suburbs in Greater Johannesburg. The estate agents saw redlining as a form of segregation of areas and people. They saw mortgage lenders as "engineers" of urban slums through redlining. This line of discussion supports arguments made by activists and other human rights organisation that fight segregation of areas or people. Similar arguments have been made in the United States and the United Kingdom.

On the failure or non-existence of secondary mortgage markets in South Africa, the estate agents acknowledged that the current government had initiated positive measures but felt it was not enough to provide guarantees for mortgage lenders to lend in any area of Johannesburg. The estate agents felt more needed to be done to provide sureties for mortgage lenders.

\subsubsection{Residents}

The views of the residents of the inner-city supported the argument that mortgage lenders were to blame for all the redlining that was happening in their areas. They felt it was unfair and was a segregation measure by the financial institutions. However, it must be noted that the residents were not familiar with lending criteria applied by financial institutions in granting mortgage bonds or loans. They were also not familiar with default risks or the concept of pricing of risk that the financial institutions were applying.

\subsubsection{Property Experts}

The valuer's opinions and the building inspector's opinion that value and depreciation of real estate in 
areas that were redlined were justifiable for redlining by mortgage lenders support the arguments of the financial institutions interviewed in the research. Literature does not support the hypothesis that redlined areas are a result of negative collateral as it could not be proven in the United States that there was a correlation between falling real estate prices and redlining of areas. This was recorded in the study by Swago [9] that entitled "Low cost housing developments have no effect on the values of neighbouring properties".

The experts' opinion vested more on the values of the real estate than on the attributes of the residents as they felt financial institutions considered extensively the future values of the real estate in granting mortgage bonds.

\subsubsection{Property Project Managers}

Project managers had a better understanding of the subject of redlining in Greater Johannesburg and also had better success in getting mortgage bonds in areas that were perceived to be redlined. The project managers had established firm relationships with the mortgage lenders and worked closely with them in raising funding for their projects in the inner-city of Johannesburg. The mortgage lenders even went further to advise them on how to better succeed in getting mortgage bonds in the inner-city. However, they were also faced with the same challenges as the residents, especially the deteriorating conditions of the inner-city of Johannesburg and the crime. They even went further in understanding the extent of exposure of the mortgage lenders in high risk areas like the inner-city of Johannesburg. None the less, they also acknowledged the existence of redlining in the inner-city of Johannesburg.

\subsubsection{Civic Organisations}

Civic organisations in Greater Johannesburg followed the argument of the activists and the residents of the inner-city of Johannesburg. They believed that racial and economic segregation was a major factor in determining areas that were redlined.
They followed their arguments with examples like, the fact that the majority of the people living in the inner-city, where redlining was prevalent, were blacks and low income earners, hence the financial institutions found it was justifiable to redline such areas on the basis of high default risk. Studies in the United States of America were inconclusive on determining the correlation between racial groups in the United States and higher default risks. Such findings are recorded in the study completed by Andrew Holmes [5].

However, civic organisations in South Africa were restrained as they could not prove their assumptions since financial institutions were not compelled to reveal their mortgage bonds applications' records. There were no laws in South Africa similar to the Home Mortgage Disclosure Act of the United States.

\subsection{Mortgage Lenders/Financial Institutions}

The financial institutions took a hard line on the discussions of redlining. They defended their lending criteria on the bases of sound financial decisions according to lending practices and government regulations.

The biggest problem in Greater Johannesburg, though particularly in the areas that were redlined, was the poor demographic profile of the residents. This presented the financial institutions with a case of poor real estate characteristics coupled with applicants who had poor credit worthiness, resulting in the areas being prone to be segregated and redlined.

The financial institutions all objected to racial bias on their practices and emphasized that their criteria was based on credit worthiness, irrespective of race. In South Africa, the racial bias is complicated by the demographic make-up of the income levels, whereby most of the poor and low income earners are the blacks and most of the rich and high income earners are the whites. It is often easier to blame everything on race rather that income levels when one considers why certain racial groups are not getting mortgage 
bonds approval, for example.

\section{What the South African Government and Society Did to Combat Redlining}

In the United States, redlining policies began in the 1930s and were based on racial bias. In the South African scenario, the lending institutions, together with developers, withdrew from the "black" townships in the 1980s (notably in 1984 and 1986) because of boycotts to mortgage repayments. These boycotts were not directed at only financial institutions, but at all service providers in the "black" townships in protest against the government's segregation laws. This was at the height of the struggle against apartheid. The communities in the "black" townships developed a culture of not paying for services. The financial institutions withdrew from whole areas without appraisal of investment opportunities and risks. In a similar way, electricity would be switched off from whole areas without discrimination of who has paid or not. Lending to the "black" townships was considered off-limits.

In October 1994, the post-apartheid government made an agreement known as the Housing Accord with the financial institutions to return to the black townships. The accord can be summarised by the following statements made by the communities and the association of mortgage lenders, respectively: "we commit ourselves to an intensive campaign to change the hostilities between financial institutions, local governments and communities and bring to an end the tradition of non-payment for rent and bond boycotts..." and "greater accessibility of credit for lower income earners can dramatically reduce the numbers of families relying solely on government housing subsidy. Absent from the lower end of the housing market for some time, we representatives of the banks and broader financial sector commit ourselves to a resumption of lending on a scale large enough to allow a significant number of South Africans to become first time home owners".
The accord was followed by the ROU (Record of Understanding) signed by the government and the Association of Mortgage Lenders. The financial institutions pledged to provide fifty thousand loans to low income earners in the black townships and the government pledged their commitment to encourage the residents to repay the loans. The government launched the "Masakhane" campaign. "Masakhane" means "let's develop one another".

In addition, the post 1994 government took it upon itself to encourage businesses to re-invest in the inner-cities of all major towns in South Africa. The government introduced tax breaks under UDZ (urban development zones), passed under the Revenue Laws Amendment of 2003, whereby inner-city areas in all major towns around the country were demarcated and any investment companies make within the demarcated areas receives a tax break. This has encouraged re-investment into the inner-city of Johannesburg and there has been a surge in development projects from 2004 to 2010. There have been a lot of conversions of office buildings in Johannesburg to rental stock. Security has also been improved and the overall conditions in the inner-city have improved.

During the research, there were a number of housing trusts and a mortgage indemnity fund that were operating in Greater Johannesburg. One of these funds was the ICHUT (Inner-City Housing Upgrading Trusts), then there was the MIF (Mortgage Indemnity Fund). The main objective of the trusts and funds was to combat redlining and allow financial institutions to return to areas where they had stopped lending to. They assisted with projects' deficiencies and additional risks associated with redlined areas. The areas covered by the trusts and funds were the inner-city and the "black" townships where financial institutions had stopped lending in the 1980s and early 1990s. The trusts and the funds offered various forms of assistance including short-term insurance and sureties (indemnity). The trusts and funds also engaged with the communities to try and stabilise the 
environments and bring stability to an area where lending had ceased. One way they carried out this was to encourage ownership and owner-occupancy in the inner-city. They aimed to bring up the owner-occupancy to about $30 \%$ as they believed higher owner-occupancy resulted in more stable environments.

The MIF's other objective was to eradicate redlining completely in Johannesburg and bring about an environment that was conducive to investment in the whole of Johannesburg. The MIF covered political risks and operated mostly in areas where there were rents and bonds boycotts as a result of the resistance to apartheid. They engaged with the communities and encouraged them to pay for services and bonds' instalments. They also assisted in ensuring there was rule of law and order in the areas and supported all court orders that were made in the areas which had previously experienced civil unrest.

\section{Conclusions and Further Research}

The research showed that redlining practice existed in Greater Johannesburg. During the research, the findings brought to light the reasons for redlining: why mortgage lenders were engaged in the redlining practice. The research also brought to light some strategies that could be used to combat the redlining practice. The research did not test if the measures taken by the South African government and society were effective in eradication the redlining practice in Greater Johannesburg completely.
This research could be extended to other areas to determine if the redlining practice exists in those areas. The literature review showed that it is applicable to many areas around the world. More research, on strategies and measures for combating redlining, needs to be made for effective eradication of the redlining practice.

\section{References}

[1] A. Kirby, The Inner-City-Causes and Effects, Rationalist Press Association Books, Retailing and Planning Associates, England, 1978.

[2] P. Bond, How to squeeze Johannesburg's northern suburbs, The Weekly Mail 2 (1993) 11.

[3] O. Crankshaw, C. White, Racial desegregation and the origin of slums in the inner-city of Johannesburg, in: Group for Human Resources, South Africa: Human Resources Research Council, Johannesburg, 1992, pp. 10-12.

[4] C.M. Nsibande, Redlining of Residential Properties in Greater Johannesburg, An unpublished research report, University of Witwatersrand, Johannesburg, South Africa, 1999.

[5] A. Holmes, Neighborhood racial composition and mortgage redlining: A nationwide analysis, Journal of Real Estate Portfolio Management 6 (1) (2000) 37.

[6] G.D. Squires, W. Velez, Mortgage lending and race: Is discrimination a factor?, Environment and Planning A 28 (7) (1996) 1199.

[7] W.F. Sharpe, Capital asset prices: A theory of market equilibrium under conditions of risk, The Journal of Finance 19 (3) (1964) 425-444.

[8] R.G. Roberts, The Feds' Sham settlement with Shawnut, Economic Viewpoint—Business Week 1 (1994) 22.

[9] D. Swago, Low cost housing developments have no effect on the values of neighbouring properties, The Appraisal Journal 66 (1996) 27. 